\title{
Evaluation of Gerbera Varieties for Growth and Floral Characters Grown Under Greenhouse Condition
}

\author{
S.S. Soni and A.K. Godara* \\ Department of Horticulture, CCS Haryana Agricultural University Hisar, \\ Haryana (India)-125004 \\ *Corresponding author
}

\begin{tabular}{|c|c|}
\hline & A B S T R A C T \\
\hline & $\begin{array}{l}\text { The experiment was conducted at Hi-Tech Greenhouse of CCS Haryana Agricultural } \\
\text { University, Hisar, Haryana during } 2008-09 \text { to evaluate the different gerbera varieties under } \\
\text { greenhouse condition. Ten gerbera varieties viz. Amulet. Dana Ellen. Doni. Goliath. Paco }\end{array}$ \\
\hline Keywords & Rosalin, Salvadore, Savannah, Sunway and Winter Queen were selected for evaluation. \\
\hline $\begin{array}{l}\text { Greenhouse } \\
\text { Gerbera } \\
\text { jamesonii, Dana } \\
\text { Ellen, Goliath }\end{array}$ & $\begin{array}{l}\text { Healthy plants were planted on raised beds in two rows at spacing of } 35 \times 30 \mathrm{~cm} \text { in March, } \\
\text { 2008. There was a significant variation in plant growth, cut flower yield and flower quality } \\
\text { parameters of different varieties of gerbera. Plant height }(41.27 \mathrm{~cm}) \text {, number of leaves } \\
(42.60) \text {, plant spread }(62.80 \mathrm{~cm}) \text { and leaf area }\left(6425.60 \mathrm{~cm}^{2}\right) \text { was recorded maximum in }\end{array}$ \\
\hline Article Info & and var. Dana Ellen took the minimum number of days for flower opening. Dana Ellen \\
\hline $\begin{array}{l}\text { Accepted: } \\
26 \text { April } 2017 \\
\text { Available Online: } \\
10 \text { May } 2017\end{array}$ & $\begin{array}{l}\text { produced the maximum number (21.13) of quality cut flowers followed by Amulet }(17.13) \\
\text { during the period under study. Dana Ellen and Doni produced the longest stalk }(62.80 \mathrm{~cm} \\
\text { and } 61.80 \mathrm{~cm} \text {, respectively) and the maximum diameter of flower }(14.22 \mathrm{~cm} \text { and } 13.87 \mathrm{~cm} \text {, } \\
\text { respectively). In this experiment, we have been looked for suitable cultivar of gerbera for }\end{array}$ \\
\hline & $\begin{array}{l}\text { greenhouse production. Out of ten cultivars, Dana Ellen responds better and showed } \\
\text { highest vegetative growth and flower production under protected cultivation but cultivar } \\
\text { Goliath not found suitable for all vegetative and floral characteristics. }\end{array}$ \\
\hline
\end{tabular}

\section{Introduction}

Gerbera (Gerbera jamesonii Bolus ex Hooker F.) belongs to family Asteraceae and is native of Africa. Gerbera is cultivated throughout the world including U.K., Netherlands, Poland, Belgium, Spain, USA, Germany, and Italy under a wide range of climatic conditions for its attractive flowers. Gerbera is one of the most popular commercial cut flower in the world and occupies the fourth place among the cut flowers (Sujatha et al., 2002). Gerbera add colors to any room or garden to create festive and elegant display.
It is highly suitable for beds, borders, pots, rock gardens and also flower arrangement or bouquet and has a longer vase life (Naik et al., 2006). It is difficult to get good quality cut blooms of gerbera under open field condition. Hence, to meet the qualitative and quantitative standards, the high yielding and long lasting varieties have to be grown under protected conditions like greenhouse/ polyhouse. Significant relationships were found between different growing media parameters with flower quality and yield 
parameters of gerbera under protected cultivation (Panj et al., 2014). Performance of gerbera varieties varies with the region, season and other growing conditions (Horn et $a l .$, 1974). The limited research work has been done on the evaluation of new varieties to suit the local conditions. As there is always demand for novel types with high yielding varieties, it is needed to evaluate new varieties for their quantitative and qualitative parameters to recommend the suitable variety for the region.

\section{Materials and Methods}

The present investigation entitled "Evaluation of gerbera varieties for growth and flowering character grown under greenhouse condition" was carried out at $\mathrm{Hi}$-Tech Greenhouse of CCS Haryana Agricultural University, Hisar during 2008-09. Ten gerbera varieties viz., Amulet, Dana Ellen, Doni, Goliath, Paco, Rosalin, Salvadore, Savannah, Sunway and Winter Queen were selected for this study. Healthy tissues were planted at the spacing of $35 \times 30 \mathrm{~cm}$. The experiment was laid out in a completely randomized design with three replications. Cultural practices viz., irrigation, fertigation and weeding were attended uniformly. Observations were recorded on plant height, number of leaves, plant spread, leaf area, number of suckers, number of days taken for flower bud appearance, flower bud opening, number of flowers per plant, flower diameter and stalk length. The statistical method described by Panse and Sukhatme (1967) was followed for analysis and interpretation of the experimental results.

\section{Results and Discussion}

\section{Growth parameters}

The vegetative growth was measured in terms of plant height, number of leaves, plant spread, leaf area and number of suckers (Table 1). Among the 10 varieties evaluated, the maximum plant height was observed in variety Dana Ellen $(41.27 \mathrm{~cm})$ followed by Amulet $(39.00 \mathrm{~cm})$, Savannah $(35.53 \mathrm{~cm})$, Winter Queen $(34.87 \mathrm{~cm})$, Salvadore (33.00 $\mathrm{cm})$, Sunway $(32.53 \mathrm{~cm})$, while variety Goliath $(24.73 \mathrm{~cm})$ recorded the minimum plant height followed by Paco $(29.87 \mathrm{~cm})$. The marked variation in the plant height may be due to varietal characters. Similar observations have been reported by Singh and Ramchandran (2002), Wankhede and Gajbhiye (2013), Kumari et al., (2010). Biradar and Khan (1996) also reported similar results in plant height in different varieties of gerbera. Leaf productions decide the spread of plant and are the important functional unit for photosynthesis, influencing the growth and flower yield. Among the varieties studied Dana Ellen was found to be significantly superior over others with respect to number of leaves (42.60) followed by Amulet(39.60), Winter Queen(36.67) and Savannah(32.73), while variety Goliath recorded the minimum number of leaves (23.13) followed by Paco (24.60). The number of leaves differed may be due to the genetic makeup of the cultivars. Variation in leaf production per plant has also been reported by Kandpal et al., (2003), Naik et al., (2006) and Sarmah et al., (2014) in gerbera. The effect of cultivars on variation in number of leaves per plant has also been advocated by Kumar and Kumar (2001).

Plant spread was observed to be greater in Dana Ellen $(62.80 \mathrm{~cm})$ followed by Amulet $(57.73 \mathrm{~cm})$, Winter Queen $(55.47 \mathrm{~cm})$, Savannah $(53.53 \mathrm{~cm})$, Doni $(50.67 \mathrm{~cm})$, Salvadore $(48.33 \mathrm{~cm})$, Sunway $(45.67 \mathrm{~cm})$ and Rosalin $(43.53 \mathrm{~cm})$, while it was least in Goliath $(37.53 \mathrm{~cm})$ followed by Paco (42.93 $\mathrm{cm})$. The variations in the plant spread may be due to additive gene effect. This finding in line with earlier work carried out by Singh and Ramchandran (2002) who found that cultivar Lyonella recorded the maximum plant spread while minimum plant spread recorded in cv. Whitsun and stated that the 
variation in plant spread may be due to varietal character. Similar results have been reported by Vidalie et al., (1985), Nair and Medhi (2002) in gerbera. The leaf area of different varieties of gerbera at different stages varied significantly. The maximum leaf area was recorded in varieties Dana Ellen $\left(6425.60 \mathrm{~cm}^{2}\right)$ followed by Amulet $(5048.20$ $\mathrm{cm}^{2}$ ), Winter Queen (4723.14 cm), Savannah $(3829.49 \mathrm{~cm})$, Salvadore $(3241.94 \mathrm{~cm})$, Doni $(3185.50 \mathrm{~cm})$, Sunway $(2686.23 \mathrm{~cm})$, Paco $(2654.02 \mathrm{~cm})$ whereas, the minimum leaf area was recorded in variety Goliath $2439.80 \mathrm{~cm}^{2}$ ) followed by Rosalin $(2561.58 \mathrm{~cm})$. The variation in the leaf area in different varieties of gerbera also may be due to additive gene effect. Similar results were also recorded by Naik et al., (2006) who attributed it to the genetic makeup of the cultivars and the growing conditions. The results of the present study are in conformity with Nair and Medhi (2002) who also recorded significant variation among different gerbera and attributed it to inherent genetic factors.

Studies revealed better ability of Dana Ellen followed by Amulet regarding production of suckers. Maximum number of suckers was obtained from Dana Ellen (6.80) followed by Amulet (6.67), Winter Queen (5.73) but there was non-significant difference between Doni and Savannah with respect to the number of suckers. Minimum number of suckers was observed from cv. Goliath (3.20) followed by Paco (3.27). The marked variation in number of suckers appears to be genotype-specific as suggested by Singh and Ramchandran, 2002. Gurav et al., 2004 had also been reported variation in number of suckers in different gerbera varieties grown under greenhouse condition.

\section{Floral Parameter}

The number of days for flower bud appearance from transplanting and flower opening were significantly different among all the cultivars of gerbera studied (Table 2 ). The cultivar Amulet (61.33 days) was significantly earlier for flower bud appearance followed by Doni (65.47 days), Paco (67.73 days), Goliath(71.20 days)whereas; Winter Queen (91.73 days) took the maximum number of days followed by Rosalin (85.33 days). The results for days to opening of first flower after flower bud appearance was clearly indicated that Dana Ellen (16.87 days) required the minimum number of days for flower opening followed by Salvadore (17.07 days), Sunway (17.27 days), Amulet (17.60 days), Rosalin (17.73 days), Paco (18.27 days), Doni (18.80 days), Savannah (19.07 days) while Winter Queen (20.27 days) has taken the maximum number of days followed by Goliath (19.20 days). The variations among the varieties with respect to days required for flower bud appearance from planting and days required for flower opening from flower bud appearance can be attributed to differences in genetic makeup of cultivars. The results of the present study are in conformity with Kumar and Kumar (2001) who also recorded significant variation among different gerbera for flowering characters and attributed it to genetic makeup of varieties. Gaikwad and Paul (2001) have also observed similar results in chrysanthemum.

Flower yield and its quality parameters decide the significance of the particular genotypes, which are suitable for commercial cultivation. In the present investigation variety Dana Ellen produced the maximum (21.13) number of flowers per plant followed by Amulet (17.13), Savannah (14.60), Winter Queen (14.33), Sunway (13.53), Doni (13.27), Salvadore (12.20), Paco (11.60), respectively whereas, Goliath produced the minimum (9.53) number of flower per plant. The increased in flower yield might be attributed to the greater plant growth. The number of leaves, plant spread and leaf area was the 
maximum in variety Dana Ellen resulting in production and accumulation of maximum photosynthates. Singh and Singh (2006) reported that the flower yield showed positive correlation with leaves per plant, plant spread and plant height in gerbera varieties. A positive correlation of flower production with number of leaves in gerbera was also reported by Anuradha and Gowda (2002) in gerbera varieties. The results are in the accordance with the findings of Nair and Medhi (2002) in gerbera grown under protected conditions. Biradar and Khan (1996) also reported variations in total yield of flowers in gerbera grown under greenhouse condition.

Table.1 Performance of gerbera varieties for growth parameters grown under greenhouse condition

\begin{tabular}{|c|c|c|c|c|c|}
\hline Varieties & Height(cm) & No. of leaves & $\begin{array}{c}\text { Plant } \\
\text { spread(cm) }\end{array}$ & $\begin{array}{c}\text { Leaf } \\
\text { area }\left(\mathbf{c m}^{\mathbf{2}}\right)\end{array}$ & No. of suckers \\
\hline Amulet & 39.00 & 39.60 & 57.73 & 5048.20 & 6.67 \\
\hline Dana Ellen & 41.27 & 42.60 & 62.80 & 6425.60 & 6.80 \\
\hline Doni & 31.53 & 30.40 & 50.67 & 3185.50 & 5.27 \\
\hline Goliath & 24.73 & 23.13 & 37.53 & 2439.80 & 3.20 \\
\hline Paco & 29.87 & 24.60 & 42.93 & 2654.02 & 3.27 \\
\hline Rosalin & 30.27 & 26.00 & 43.53 & 2561.58 & 3.60 \\
\hline Salvadore & 33.00 & 31.27 & 48.33 & 3241.94 & 4.87 \\
\hline Savannah & 35.53 & 32.73 & 53.53 & 3829.49 & 5.27 \\
\hline Sunway & 32.53 & 28.13 & 45.67 & 2686.23 & 4.73 \\
\hline Winter Queen & 34.87 & 36.67 & 55.47 & 4723.14 & 5.73 \\
\hline CD. at5\% & $\mathbf{1 . 2 1}$ & $\mathbf{1 . 4 3}$ & $\mathbf{1 . 9 3}$ & $\mathbf{2 4 3 . 2 8}$ & $\mathbf{1 . 1 7}$ \\
\hline
\end{tabular}

Table.2 Performance of gerbera varieties for floral characters grown under greenhouse condition

\begin{tabular}{|c|c|c|c|c|c|}
\hline Varieties & $\begin{array}{c}\text { Days for } \\
\text { flower bud } \\
\text { appearance }\end{array}$ & $\begin{array}{c}\text { Days for } \\
\text { flower } \\
\text { opening }\end{array}$ & $\begin{array}{c}\text { Number of } \\
\text { flowers }\end{array}$ & $\begin{array}{c}\text { Stalk } \\
\text { length(cm) }\end{array}$ & $\begin{array}{c}\text { Flower } \\
\text { diameter(cm) }\end{array}$ \\
\hline Amulet & 61.33 & 17.60 & 17.13 & 53.65 & 11.66 \\
\hline Dana Ellen & 73.60 & 16.87 & 21.13 & 62.80 & 14.22 \\
\hline Doni & 65.47 & 18.80 & 13.27 & 61.80 & 13.87 \\
\hline Goliath & 71.20 & 19.20 & 9.53 & 40.81 & 9.76 \\
\hline Paco & 67.73 & 18.27 & 11.60 & 42.86 & 10.00 \\
\hline Rosalin & 85.33 & 17.73 & 10.40 & 43.04 & 10.05 \\
\hline Salvadore & 78.40 & 17.07 & 12.20 & 43.55 & 10.46 \\
\hline Savannah & 82.27 & 19.07 & 14.60 & 45.28 & 11.50 \\
\hline Sunway & 76.20 & 17.27 & 13.53 & 50.10 & 10.84 \\
\hline Winter Queen & 91.73 & 20.27 & 14.33 & 51.96 & 10.90 \\
\hline CD at 5\% & $\mathbf{1 . 3 9 8}$ & $\mathbf{0 . 9 3}$ & $\mathbf{1 . 2 1}$ & $\mathbf{2 . 2 7}$ & $\mathbf{0 . 6 5}$ \\
\hline
\end{tabular}


The stalk length and flower diameter are very important parameters for gerbera cut flower which decide the quality. Significant differences were observed among the different varieties for stalk length and flower diameter in gerbera. Dana Ellen and Doni were found to be superior with respect to stalk length $(62.80 \mathrm{~cm}, 61.80 \mathrm{~cm}$, respectively) and flower diameter $(14.22 \mathrm{~cm}, 13.87 \mathrm{~cm}$, respectively) whereas, Goliath recorded shorter stalk length $(40.81 \mathrm{~cm})$ and smaller flowers $(9.76 \mathrm{~cm})$. The increase in flower size was probably due to bigger ray florets. The above results are in conformity with the findings of Naik et al., (2006). Kandpal et al., (2003), Singh and Ramchandran (2002), Ahlawat et al., (2012) and Mahmood et al., (2013) found that the flower quality parameters such as stalks length and diameter of flower were significantly different among the varieties and attributed these differences to inherent characters of the individual cultivars.

\section{References}

Ahlawat, T.R., Barad, A.V. and Jat, G. 2012. Evaluation of gerbera cultivars under naturally ventilated polyhouse.Indian Journal of Horticulture. 69(4): 606-608.

Anuradha, S. and Gowda, J.V.N. 2002. Interrelationship between growth and yield parameters with flower yield in gerbera. J. Orn. Hort. 5(1): 35-37.

Birader, M.S. and Khan, M.M. 1996. Performance of exotic gerbera varieties under low cost plastic greenhouse. The Lai Bough J. 43 (3\&4): 46-52.

Gaikwad, A.M. and Patil, S.S.D. 2001. Evaluation of chrysanthemum varieties under open and polyhouse conditions. $J$. Orn. Hort. New Scries. 4(2): 95-97.

Gurav, S.B., Singh, B.R., Katwate, S.M., Sabale, R.N., Kakade, D.S. and Dhane, A.V. 2004. Effect of nutritional level on yield and quality of gerbera J. Orna. Hort. 7(3-4): 239-242.
Horn, W., Wricke, G. and Weber, W.E. 1974. Genotypic and environmental effects on characters expression in Gerbera jamesonii. Gareten bauwissenssenschaft. 39(3):289-300.

Kandpal, K., Kumar, S., Srivastava, R., and Chandra, R. 2003. Evaluation of gerbera (Gerbera jamesonii) cultivars under tarai conditions. J. Orn. Hort. 6(3): 252255.

Kumar, D. and Kumar, R. 2001. Effect of modified environments on gerbera. $J$. Orn. Hort., New Series. 4(1): 33-35.

Kumari, A., Patel, K.S. and Nayee, D.D. 2010. Evaluation of different cultivars of gerbera (Gerbera jamisonii Bolus ex hookerF.) for growth, yield and quality grown under fan and pad cooled green houseconditions. The Asian Journal of Horticulture. 5(2): 309-310.

Mahmood, M.A., Ahmad, N. and Khan, M.S.A. 2013. Comparative Evaluation of Growth, Yield and Quality Characteristics of Various Gerbera (Gerbera jamesonii L.)Cultivars under Protected Condition.Journal of Ornamental Plants. 3(4): 235-241.

Naik, B.H., Chauhan, N., Patil, A.A., Patil, V.S. and Patil, B.C. 2006. Comparativeperformance of gerbera (Gerbera jamesonii Bolusex Hooker F.) cultivar undernaturally ventilated polyhouse. J. Orn. Hort. 9(3): 204-207.

Nair, S.A. and Medhi, R.P. 2002. Performance of gerbera cultivars in the Bay Island. Indian J. Hort. 59(3): 322325.

Pang, F.G., Kumari, S. and Parmar, P.B. 2014. Effect of growing media properties and its correlation study in gerbera production. The Bioscan. 9(1): 79-83.

Panse, V.G. and P.V. Sukatme, 1967. Statistical Methods for Agricultural Workers. Indian Council of Agricultural Research, New Delhi, p. 155. 
Sarmah, D., Kolukunde, S. and Mandal, T. 2014. Evaluation of gerbera varieties for growth and flowering under polyhouse in the plains of west Bengal. International Journal of Scientific Research.3: 135-136.

Singh, K.P. and Ramchandran, N. 2002. Comparison of greenhouse having natural ventilation and fan pad evaporative, cooling systems for gerbera production. J. Orn. Hort., New Series. 5(2): 15-19.

Singh, K.P. and Singh, M.C. 2006. Association analysis in gerbera (Gerbera jamesonii Bolusex Hooker F.) grown under naturally ventilated greenhouse. Prog. Hort. 38(2): 199-204.

Sujatha, A., Shiva, K.N. and Beena, S.J. 2002. Gerbera - A potential and profitable cut flowers. Kisan World. 59-60.

Vidalie, H.L., Rivera, L.M. and Charperiter, S. 1985. First result of performance of gerbera cultivated on rock wool. Revue Horticoley. 262:13-18.

Wankhede, S. and Gajbhiye, R.P. 2013. Evaluation of Gerbera Varieties for Growth and Flowering under Shadenet. International Journal of Horticulture. 3(9): 42-45.

\section{How to cite this article:}

Soni, S.S. and Godara, A.K. 2017. Evaluation of Gerbera Varieties for Growth and Floral Characters Grown Under Greenhouse Condition. Int.J.Curr.Microbiol.App.Sci. 6(5): 27402745. doi: https://doi.org/10.20546/ijcmas.2017.605.307 